\title{
Modal Sosial Dalam Pengelolaan Hutan Produksi Pada Lembaga Masyarakat Desa Hutan (LMDH) Desa Pandantoyo Kabupaten Kediri
}

\author{
Naufal Romzy ${ }^{1, *}$, Triwahyudianto ${ }^{1}$, Nila Restu Wardani ${ }^{1}$ \\ ${ }^{1}$ Program Studi Pendidikan Geografi, UniversitasKanjuruhan Malang, Malang 65148, Indonesia \\ Email: "naufalromzy16@gmail.com; v.diant@yahoo.com; nilarestu@unikama.ac.id
}

Dikirim : 20 Maret 2019

Diterima: 30 Maret 2019

\begin{abstract}
Abstrak:Hutan produksi merupakan kawasan hutan yang dimanfaatkan untuk memproduksi hasil hutan yangkegiatannya terdiri dari pemanenan, penanaman, pengamanan, pengolahan dan pemasaran hasil kayu di hutan produksi. Modal sosial adalah kemampuan masyarakat untuk bekerjasama demi mencapai suatu tujuan bersama di dalam suatu kelompok. Modal sosial memiliki peran yang signifikan terhadap pembangunan, khususnya terhadap pembangunan berkelanjutan karena modal sosial merupakan salah satu cara mencapai kemajuan bersama. Penelitian ini bertujuan untuk mengetahui tiga unsur modal sosial yaitu kepercayaan (trust), jaringan sosial (network) dan norma (norms) yang terjalin antara Perum Perhutani RPH Pandantoyo, LMDH PHS dan Masyarakat Desa Hutan. Penelitian ini menggunakan pendekatan kualitatif deskriptif. Metode yang digunakan yaitu observasi, wawancara dan dokumentasi. Adapun informan yang dijadikan sebagai narasumber adalah Kepala Perum Perhutani, Ketua LMDH PHS dan Pesanggem (petani yang menggarap lahan hutan milik Perhutani). Teknik analisis data menggunakan wawancara dan dokumentasi, kemudian data diolah sesuai dengan fokus penelitian sehingga ditemukan temuan data. Hasil penelitian menunjukkan bahwa modal sosial di dalam pengelolaan hutan produksi terjalin baik karena tingginya rasa kepedulian diantara Perum Perhutani RPH Pandantoyo, LMDH PHS dan masyarakat yang mengelola hutan. Perum Perhutani dan LMDH meyakini bahwa dengan bekerjasama dengan masyarakat akan memberikan manfaat yang baik dari segi ekologi maupun ekonomi. Tanpa adanya modal sosial yang dianut oleh masyarakat maka kerjasama mereka dengan pihak yang Perhutani dan LMDH dalam mengelola hutan produksi tidak akan bertahan hingga sekarang. Diharapkan masyarakat maupun stakeholder yang terkait dalam pengelolaan hutan yang terjalin saat ini mampu dipertahankan dalam pengelolaan hutan produksi kedepan lebih baik lagi.
\end{abstract}

Kata kunci:Hutan produksi, modal sosial, LMDH

\section{Pendahuluan}

Indonesia merupakan salah satu negara yang memiliki sumber daya alam yang sangat melimpah salah satunya adalah hutan. Luas hutan di negara Indonesia saat ini seluas 93,6 juta ha (Kementrian Lingkungan Hidup dan Kehutanan: 2017), adanya hutan yang melimpah memiliki potensi tersendiri bagi kehidupan manusia untuk memenuhi kebutuhan sosial, ekonomi, dan lingkungan melalui kegiatan pengelolaanya dan pemanfaatannya. Hutan adalah sebagai salah satu Sumber Daya yang besar dan melimpah, secara ekologis manfaat hutan dapat mencegah banjir dan erosi tanah serta manfaat ekonomis yang dapat dirasakan adalah hasil kayu, madu daun dan sebagainya. Sejalan dengan meningkatnya kebutuhan kayu seperti kayu bakar maupun untuk kepentingan industri yang didorong oleh pertumbuhan penduduk yang semakin pesat tentunya memerlukan pengelolaan hutan yang baik sehingga dapat dipertanggung jawabkan untuk generasi selanjutnya.

Menurunnya kualitas lingkungan yang diakibatkan oleh degradasi hutan merupakan salah satu permasalahan yang dihadapi oleh seluruh dunia salah satunya di Indonesia, Menurut peraturan pemerintah hutan terbagi menjadi hutan lindung, hutan produksi dan hutan konservasi, berdasarkan UU No. 5 Tahun 1967 salah satu jenis hutan yang ada di Indonesia adalah hutan produksi,yang tujuannya untuk memproduksi hasil dari hutan. Perum Perhutani ditugaskan untuk mengelola hutan negara yang mana bertujuan untuk memberikan perhatian pada masalah perekonomian masyarakat desa yang bertempat tinggal di sekitar hutan. Melalui 
pola PHBM (Pengelolaan Hutan Bersama Masyarakat) berdasarkan perkumpulan yang dilakukan oleh masyarakat sekitar Desa Pandantoyo, bahwa dengan adanya suatu organisasi sosial ekonomi kerakyatan yang bersifat pemberdayaan dan kebersamaan dalam kesetaraan serta hal-hal yang dapat membangun kondisi sosial.

Perum Perhutani masa lalu kurang memperhatikan kondisi sosial ekonomi masyarakat pinggiran hutan yang kemudian memunculkan ketidakseimbangan dalam pengelolaan hutan dan meningkatnya kerusakan hutan dan konflik dengan masyarakat sekitar hutan dengan Perhutani. Sehingga perlu adanya kerjasama antara perhutani dengan masyarakat sekitar hutan. Melalui pola PHBM (Pengelolaan Hutan Bersama Masyarakat) berdasarkan perkumpulan yang dilakukan oleh masyarakat sekitar Desa Pandantoyo, bahwa dengan adanya suatu organisasi sosial ekonomi kerakyatan yang bersifat pemberdayaan dan kebersamaan dalam kesetaraan serta hal-hal yang dapat membangun kondisi sosial.

LMDH merupakan suatu wadah yang mana untuk meningkatkan peran serta masyarakat dalam mendukung program kerja pemerintah dengan cara melestarikan hutan agar tetap hijau dan lestari, selain itu juga sebagai bentuk pencegahan terhadap penebangan liar (illegal logging) dan kerusakan hutan. LMDH yang berada di Dusun Gogorejo Desa Pandantoyo merupakan program PHBM. Wilayah kerja LMDH ini meliputi HPD (Hutan Pangkuan Desa) pandantoyo yang termasuk didalamnya kawasan hutan negara yang dikelola oleh Perum Perhutani KRPH (Kepala Resort Polisi Hutan) Pandantoyo seluas 76 ha. Maksud dari kesepakatan bersama ini adalah bentuk wujud dari pengelolaan sumber daya hutan bersama masyarakat. Dalam pengelolaan kawasan hutan, masyarakat pinggiran hutan mempunyai kewenangan dan peranan dalam hal melakukan pengelolaan kawasan hutan.

Berdasarkan kondisi ekonomi dan sosial yang melatarbelakangi terbangunnya pengelolaan hutan produksi di Desa Pandantoyo Kabupaten Kediri, dapat disimpulkan bahwa pengelolaan hutan produksi tersebetut terbangun oleh adanya keterkaitan modal sosial yang kuat. Aturanaturan dalam pengelolaan hutan, kepercayaan dan jaringan dalam pengelolaan hutan produksi sesuai dengan konsep modal sosial yang dikemukakan oleh Putnam (1993, 1998), Coleman (1998), dan Fukuyama (1995). Tujuan dari penelitian ini adalah bagaimana modal sosial masyarakat dalam pengelolaan Hutan Produksi dalam Program Pengelolaan Hutan Bersama Masyarakat (PHBM) di Desa Pandantoyo Dusun Gogorejo Kabupaten Kediri.

Hasil penelitian ini diharapkan dapat berguna bagi a) bagi kalangan akademisi, menjadi bahan referensi untuk keperluan studi-studi terkait, b) bagi masyarakat, menambah pengetahuan serta memberi informasi mengenai modal sosial Perum Perhutani melalui LMDH dengan program PHBM, c) bagi pemerintah, memberikan rekomendasi kebijakan bagi para pihak yang berkepentingan dalam pengelolaan hutan.

\section{Metode Penelitian}

Penelitian ini menggunakan pendekatan kualitatif dengan jenis penelitian secara deskriptif, karena berujuan mengungkap situasi sosial tertentu degan mendeskripsikan kenyataan secara benar. Jenis penelitian deskriptif kualitatif bertujuan memahami fenomena dalam konteks sosial secara alamiah dengan mengedepankan proses interaaksi komunikasi yang endalam antara penelii dengan fenomen yang diteliti. Teknik pengumpulan data pada penelitian ini menggunakan metode observasi, wawancara dan dokumentasi. Dimana penelitian ini terdapat kunci informan yang terdiri dari: kepala Perum Perhutani, Ketua LMDH PHS, dan Pesanggem. 


\section{Pengumpulan Data}

Observasi

Melakukan pengamatan langsung pada kegiatan pengelolaan hutan, peneliti mencatat hasil observasi tersebut dalam bentuk catatan lapang yang akan berguna sebagai pelengkap dokumentasi. Kegiatan observasi bertujuan untuk memudahkan peneliti untuk mendapatkan sumber otentik dan membantu menjawab permasalahan yang akan dikaji.

\section{Wawancara}

Wawancara yang digunakan dalam penelitian ini dengan terstruktur kepada responden atau informan dengan menggunakan kuesioner, wawancara terstruktur di lakukan untuk mendapatkan data berupa karakteristik sosial masyarakat desa hutan, lembaga dan Perhutani. Target responden yang Kepala Desa, Ketua LMDH, Aggota LMDH, Perhutani, Mantri/Mandor dan Masyarakat.

\section{Dokumentasi}

Pengumpulan data-data sekunder yang mendukung penelitian melalui pencatatan data dari kantor desa, kecamatan, kabupaten, instansi dan laporan yang terkait dengan penelitian Data sekunder yang dikumpulkan berupa keadaan fisik lokasi (letak dan luas) dan keadaan sosial, ekonomi dan budaya (penduduk, mata pencaharian, pendidikan, sarana ekonomi dan perdagangan) di Desa Pandantoyo.

\section{Analisis Data}

Data analisis pada penelitian ini menggukan metode analisis kualitatif dengan model Miles dan Huberman. Analisis data dalam kualitatif dilakukan secara interaktif dan berlangsung secara terus menerus sampai datanya jenuh (Huberman dalam Sugiyono, 2017:133). Aktivitas dalam analisis data yaitu, data Reduction, data Display, dan data Drawing/Verification.

Data Reduction (Penyajian Data)

Data yang diperoleh dari lapangan cukup banyak, untuk itu maka perlu dilakukan analisis data melalui reduksi data. Dengan demikian data yang telah direduksi akan memberikan gambaran kepada peneliti, dan mempermudah peneliti untuk melakukan pengumpulan data selanjutnya, dan mencarinya bila diperlukan.Reduksi data dapat dibantu dengan peralatan elektronik seperti laptop, dengan memberikan kode pada aspek-aspek tertentun (Sugiyono, 2017).

\section{Data Display (Penyajian Data)}

Setelah data direduksi, maka langkah berikutnya adalah mendisplay data. Pada penelitian kualitatif, penyajian data bisa dilakukan dalam bentuk uraian singkat, bagan, hubungan antar katagori, flowchart dan sejenisnya. Dengan begitu akan memudahkan peneliti untuk memahami apa yang terjadi, merencanakan kerja selanjutnya berdasarkan apa yang difahami tersebut (Miles dan Huberman dalam Sugiyono, 2017;138)

\section{Conclusion Drawing/Verification}

Langkah ketiga dalam analisis kualitatif menurut Miles and Huberman adalah penarikan kesimpulan dan verifikasi. Kesimpulan awal yang dikemukakan masih bersifat sementara, dan akan berubah bila tidak ditemukan bukti bukti yang kuat yang mendukung pada tahap pengumpulan data berikutnya. 


\section{Hasil dan Pembahasan}

\section{Modal Sosial}

Modal sosial merupakan bentuk jaringan kerja sosial dan ekonomi di masyarakat antar individu dan kelompok baik formal maupun informal yang bermanfaat dan menguntungkan, yang salah satunya terbentuk di Desa Pandantoyo dalam pengelolaan hutan produksi. Putnam (1993) mengungkapkan bahwa modal sosial merupakan pondasi dasar komunitas yang komponennya meliputi kepercayaan sosial, norma dan jaringan kerja. Kehadiran tiga komponenn yang dimaksud di masyarakat dapat menggambarkan kemampuan warga dalam menyelesaikan berbagai problem umum yang dihadapi bersama. Semakin kuat modal sosial semakin kecil kemungkinan terjadinya konflik, berikut akan dipaparkan lebih lanjut mengenai tiga unsur yang dikemukan oleh Putnam (1995) tersebut berdasarksan hasil penelitiannya.

\section{Kepercayaan (Trust)}

Salah satu unsur dari modal sosial adalah kepercayaan, karena adanya kepercayaan dapat memudahkan dalam menjalin kerjasama, banyak cara yang dapat dilakukan supaya kepercayaan berjalan dengan baik. Putnam (1995) mendefinisikan kepercayaan sebagai pelumas dari kepentingan kehidupan umum yang mana kepercayaan merupakan level paling tinggi pada tingkat komunitas, paling tinggi kemungkinan dalam kerjasama.Kepercayaan merupakan hal yang kompleks dalam lingkungan yang modern dari dua sumber yang mengikat yaitu norma dan jaringan.

Hal ini juga ditemukan didalam penelitian Fauziyah (2017) yang menyebutkan bahwa didalam kepercayaan terdapat kepentingan bersama diantara masyarakat yang menyatukan mereka dalam suatu kelompokKepercayaan (trust) menjadi salah satu unsur paling penting dalam modal sosial, karena adanya rasa percaya dapat memudahkan menjalin suatu kerjasama. Semakin besar rasa percaya maka suatu akan terbangun pula kerjasama yang kuat, Salah satunya yaitu dengan adanya nilai dan norma yang menjadi pedoman dalam bersikap dan adanya sanksi sosial yang dapat mengikat agar tidak bertindak sesuka hati. Pengelolaan Hutan Produksi di berikan pengelolaannya kepada Lembaga Masyarakat Desa Hutan (LMDH) dan rasa saling percaya yang sampai saat ini masih terpelihara, berikut penjelasan menurut Rohmat sebagai salah satu pesanggem

"(Peneliti) Kira-kira bapak juga ikut serta menjag tanaman tegakan atau tidak, (Pesaggem) saya itu tidak ikut turut serta menjaga akan tetapi kalau masalah orang mencuri kayu ya saya tegur begitu, jadi saya tidak punya hak tapi pada waktu itu rapat kerja bahwa semua harus bertanggung jawab dan turut serta menjaga begitu, (Peneliti) Jadi misalkan contohnya bapak menggarap lahan disini bararti disini itu adalah tanggungjawab bapak begitu, (Pesanggem) Ya begitu tapi tidak hanya disini saja tapi dimanapun tempat kalau ada yang mencuri kayu ya ditegur)". (Wawancara kepada Rohmat, 2018)

Penuturan salah satu pesanggem ini menegaskan bahwa terdapat anjuran, larangan dan sanksi yang mengikat masyarakat dalam memanfaatkan kawasan hutan, masyarakat tunduk dan patuh terhadap aturan aturan yang telah ditetapkan baik dari lembaga LMDH maupun dari Perum Perhutani. Keprcayaan masyarakat jelas terlihat dari pemahaman mereka akan aturan aturan dalam pengelolaan hutan dan sanksi yang akan diterima bila mereka menebang pohon tanpa izin Perum Perhutani dan lembaga LMDH. 


\section{Jaringan Sosial (Network)}

Jaringan sosial yang tercipta di Desa Pandantoyo ini adanya hubungan rasa saling ingin mengenal dan hubungan kekeluargaan baik antara pesanggem dengan anggota LMDH dan Perum Perhutani. Sedangkan dalam penelitian (Muspida 2008) modal sosial antara petani dengan petani dipengaruhi oleh adanya nilai-nilai yang terbangun dalam proses interaksi diantara mereka, seperti nilai kebersamaan, dan kesepakatan atas musyawarah dalam tudang sipulung, pengakuan atas batas-batas dan hak kepemilikan lahan, kepedulian dan saling membantu dalam hubungan timbal balik, partisipasi dalam aksi kolektif (gotong royong) serta luasnya jaringan hubungan yang dilandasi rasa saling percaya antara sesama petani.

Hal ini sejalan dengan pendapat Putnam (1993) bahwa interaksi berfungsi untuk meyebarkan informasi ke seluruh anggota yang memungkinkan mereka mampu mengambil tindakan untuk mengatasi masalah secara bersama.Dalam PHBM jaringan sosial juga membantu LMDH dalam mendapatkan tambahan pengetahuan dan teknologi tertentu sehingga memudahkan efisiensi dan efektifitas. Sehingga hubungan kekeluargaan baik antara Perum Perhutani dengan Lembaga LMDH, Lembaga LMDH dengan masyarakat terbentuk.

Jaringan sosial yang terjalin antara masyarakat atau pesanggem yang mengelola hutan juga terjalin dengan baik, karena adanya ikatan dari suatu jaringan yang dapat mepermemudah mendapat bantuan informasi secara informal dengan saling bertukar pikiran dengan orang lain, hal ini menurut penuturan Rohmat dan Sumarji,

"(Peneliti) Misalkan bapak dapat informasi itu di sebarluaskan kepada teman-teman kelompok tani atau tidak pak?, (Pesanggem) Ya jelas lah dek ya di cerita ceritakan misalkan besok mau bukakan itu caranya beli bagaima)". (Wawancara kepada Rohmat, 2018)

Jaringan sosial tidak terlepas dari kepercayaan, tanpa adanya rasa kepercayaan maka jaringan tidak akan berkembang dengan luas. Selama ini jaringan yang terjalin antara Perum Perhutani KPH Pandantoyo, LMDH PHS, masyarakat berjalan dengan baik. Jaringan yang luas juga mampu meningkatkan dalam pengelolaan hutan.Putnam (1995) menyatakan jaringan merupakan efek yang sangat kuat karena menambah biaya dari setiap pengeluaran individu.Dengan demikian jaringan tersebut dapat memfasilitasi terjalinnya komunikasi dan memungkinkan tumbuhnya kepercayaan dan memperkuat kerjasama dalam program PHBM.

\section{Norma (Norms)}

Norma di masyarakat memiliki sanksi yang berbeda-beda, norma tersebut berupa tertulis maupun tidak tertulis yang dipahami dan dipatuhi oleh masyarakat. Pada penelitian ini norma pada penelitian ini dilihat dari anggota LMDH PHS yang mengetahui aturan yang dibentuk oleh LMDH ataupun oleh Perum Perhutani baik norma yang tertulis maupun norma yang tidak tertulis. Fukuyama (2005) mengatakan norma berisi pertanyaan-pertanyaan yang berkisar nilainilai luhur seperti hakikat tuhan dan keadilan. Karakteristik yang paling penting di dalam dimensi norma adalah timbal balik. Timbal balik dapat menjadi penyeimbang, secara umum timbal balik diartikan sebagai menolong satu sama lain tanpa mengharapkan imbalan.

Evi Juita (2016) juga menyebutkan norma sosial akan sangat berperan dalam mengontrol bentuk-bentuk perilaku yang tumbuh dalam masyarakat.Norma merupakan komponen yang berisi peraturan-peraturan yang terdapat dalam suatu hubungan tertentu. Norma tumbuh dan berkembang di masyarakat dan berfungsi sebagai pedoman untuk menjaga keseimbangan dalam masyarakat.Dalam PHBM, terbentuk norma-norma baik dalam kebijakan PHBM Perum Perhutani ataupun dalam LMDH. Ketaatan masyarakat yang tergabung dalam LMDH terhadap 
norma yang ada akan membantu pencapaian tujuan program PHBM yang lebih efisien, selain itu ketaatan terhadap norma yang ada akan membantu dalam PHBM.

Norma yang dimaksud pada penelitian ini adalah norma tertulis maupun tidak tertulis yang dipahami dan dipatuhi oleh masyarakat. Norma-norma yang dijalani oleh LMDH PHS ini berasal dari pelaksanaan program PHBM yaitu, terdapat aturan tertulis maupun tidak tertulis seperti dilarangnya merusak tanaman pokok Perhutani dan juga harus melakukan sharing. Sanksi yang diberikan apabila ada yang melanggar umumnya bersifat teguran apabila yang dilanggar masih dapat toleransi, akan tetapi apabila melanggar yang bersifat merusak hutan atau perusakan tanaman pokok dari Perhutani akan dikenankan sanksi sesuai dengan hukum yang berlaku. Sebagaimana yang dikemukakan oleh Januri,

"Jadi gini yang tidak tertulis itu kan gini kesepakatan bahwa setiap orang yang bekerjasama dengan perhutani harus mentaati peraturan dari perhutani, itu kan gak usah di tulis. Kalau yang di tulis seperti yang ada di lapangan itu dilarang masuk tebangan kecuali petugas. Itu kan ada setiap kegiatan itu pasti ditulisi itu. Terus kalau ada tutup kontrak satu lokasi ini ditutup tanggal sekian laa itu orang sudah memandang itu di tutup sudah tidak boleh ada aktifitas lagi, itu masing masing petak ada". (Wawancara kepada Kepala Perum Perhutani, 2018)

Anggota LMDH atau pesanggem mengakui sudah memahami dan mengetahui tentang apa yang boleh dilakukan dan tidak boleh dilakukan. Anggota LMDH atau pesanggem umumnya melaksanakan dan mematuhi norma yang telah disepakati secara kesadaran diri. Hal ini sebagaimana yang dikemukakan oleh salah satu iforman,

"(Kalau dulu jadi kejar-kejaran dimarahi juga sekarang sudah pada pintar sendiri sudah takut sendiri kalau orang dulu itu sok sokan orangnya jadi mencuri itu seenaknya sendiri. Kalau sekarang sudah takut, takut soalnya waktu dikumpulkan di perhutani pada waktu memberi lahan kerjaan. Caranya begini lupa atau tidak jadi kayu kalau sudah hidup itu di jaga jangan dirusak kalau ada kayu tumbang kalau kecil tidak papa dibawa pulang)". (Wawancara kepada Rohmat, 2018)

Bersadarkan penuturan menurut informan perasaan takut untuk melanggar sudah ada dalam benak para pesanggem, karena bagi masyarakat desa hutan selain sudah di beri kebebasan untuk masuk kedalam hutan masyarakat juga sadar akan turut menjaga hutan karena apabila merusak hutan selain di cabut hak nya juga akan menimbulkan bencana alam. Sehingga keberhasilan modal sosial ini didukung oleh unsur-unsur modal sosial yang lain sehingga modal sosial dalam masyarakat akan tertanam.

\section{Modal Sosial Dalam Pengelolaan Hutan Produksi Terhadap Masyarakat Desa Hutan}

Modal sosial merupakan salah satu faktor penting dalam pembangunan karena mampu mempengaruhi efisiensi dan efektivitas kebijakan sehingga kajian modal sosial dalam ilmu geografi. Penelitian ini merupakan salah satu bagian dalam rangkaian modal sosial dari sudut pandang keruangan. Modal sosial seperti dalam pengelolaan hutan produksi pada Lembaga Masyarakat Desa Hutan (LMDH), dapat dikaji melalui pendekatan geografi yang salah satunya merupakan pendekatan keruangan. Menurut Yunus (2008), pendekatan dalam analisis keilmuan geografi dapat dilakukakan melalui tiga pendekatan, yaitu pendekatan keruangan (spatial approach), pendekatan ekologi (ecological approach), dan pendekatan kompleks wilayah (regional complex approach). 
Berdasarkan prespektif geografi dalam pola keruangan dimana lebih menekankan pada ke khasan sebaran (aglomerasi) keruangan fenomena geosfer. Pendekatan keruangan adalah metode analisis yang menekankan pada ekstensi ruang (space) sebagai tempat/wadah untuk menampung atau mengakomodasi kegiatan manusia dalam menjelaskan fenomena geosfer. Modal sosial dalam pengelolaan hutan produksi dapat dikaji menggunakan pendekatan keruangan ini. Aplikasi pendekatan keruangan dalam modal sosial adalah fokus pada lokasi individu dalam jaringan sebagai kunci modal sosial.

Pola keruangan juga bisa terbentuk karena adanya kegiatan atau aktivitas manusia yang dilakukan secara terus menerus sehingga bisa membentuk pola keruangan. Pola keruangan disini dilihat dari kegiatan yang dilakukan oleh Perum Perhutani, LMDH PHS dan masyarakat sekitar hutan dalam pengelolaan hutan produksi, ini menjadikan hutan berfungsi sebagaimana mestinya sehingga sebagian besar masyarakat Desa Pandantoyo terbantu dengan adanya pengelolaan hutan produksi ini. Tidak hanya itu, bagaimana lembaga-lembaga yang mengelola hutan menjaga hubungan dengan masyarakat yang sudah terjalin supaya tetap terjaga dengan baik, bahkan juga bagaimana lembaga dengan masyarakat lebih meningkatkan hubungan yang sudah terjalin selama ini. Karena ini merupakan salah satu upaya pembahasan dari sudut pandang modal sosial menggunakan pendekatan keruangan.

\section{Kesimpulan}

Berdasarkan hasil penelitian yang dilakukan di Desa Pandantoyo Dusun Gogorejo maka dapat diperoleh kesimpulan, Pertama, Tingkat kepercayaan masyarakat secara umum baik yang ditunjang oleh kerjasama antara masyarakat, kepercayaan antara Perum Perhutani RPH Pandantoyo dengan LMDH PHS terjalin baik karena mereka selalu meyakini bahwa seluruh pihak baik masyarakat mampu bekerja bersama untuk mengelola hutan produksi dengan baik. Kedua,Jaringan sosial yang terjalin dalam hubungan masyarakat dengan LMDH terjalin baik, begitupun LMDH dengan Perum Perhutani juga baik, selain dilatar belakangi oleh kekeluargaan, komunikasi dan saling percaya juga menjadi faktor dalam jaringan sosial. Ketiga, Norma atau ketaatan baik LMDH maupun masyarakat terjalin baik, atauran yang di buat oleh Perum Perhutani tidak pernah melanggar aturan aturan tersebut karena sekali melanggar akan dicabut hak dan kejasamanya. Bagi peneliti selanjutnya pengambilan data dilakukan secara bertahap dan lebih mendalam sehinga data yang diperoleh lebih valid. Serta wawancara yang dilakukan dilapangan mengikuti saran yang diberikan oleh tempat penelitian.

\section{Ucapan Terimakasih}

Puji syukur penulis sampaikan ke hadirat Tuhan Yang Maha Esa karena bimbingan, berkat dan karunia-Nya, sehingga penulis dapat menyelesaikan artikelini dengan baik. Semoga artikel ini dapat menjadi sumber referensi bagi pembaca. Penulis menyelesaikan artikel ini tidak terlepas dari bantuan banyak pihak. Oleh karena itu penulis menyampaikan terimakasih kepada: Universitas Kanjuruhan Malang sebagai tempat peneliti menuntut ilmu, Perum Perhutani RPH Pandantoyo dan LMDH PHS Desa Pandantoyo sebagai tempat penelitian, Pesanggem (petani yang menggarap lahan milik perhutani) yang telah bersedia meluangkan waktunya dan memberikan data-data serta informasi yang diperlukan penulis. 


\section{Daftar Rujukan}

Fauziyah. 2017. Modal Sosial Pada Pengembangan Hutan Kemasyarakatan Di Desa Gunung Silanu Kecamatan Bangkala Kabupaten Jeneponto. Skripsi. Program Studi Kehutanan Universitas Hasanuddin Makassar

Fukuyama, F. 2002. The Great Desruption: Hakikat Manusia dan Rekonstruksi Tatanan Sosial, Yogyakarta, CV Qalam.

Moleong, Lexy J. 2007. Metodologi Penelitian Kualitatif, Penerbit PT Remaja Rosdakarya. Offset, Bandung

Nababan Juita Evi. 2016. Modal Sosial Pada Pengelolaan Dan Pelestarian Hutan Mangrove Di Kecamatan Labuhan Maringgai Kabupaten Lampung Timur. Skripsi. Bandar Lampung. Universitas Lampung. Fakultas Pertanian

Putnam R. D. 1993. The Prosperus Community Sosial and Public Life. American Prospect (13): 35-42. (Dalam The World Bank, 1998).5-7 (Online), (http://staskulesh.com/wpcontent/uploads/2012/11/prosperouscommunity.pdf). diakses 26 November 2018

Putnam RD. 1995. Bowling alone: America's declining social capital. Journal Of Democracy. 6 (1):65-78 (Online), (https://www.historyofsocialwork.org/1995_Putnam/1995,\%20Putnam,\%20bowling\% 20alone.pdf), diakses 20 September 2018

R. Rijanta,. D.R. Hizbaron,. M.Baiquni. 2014. Modal Sosial Dalam Manajemen Bencana. Yogyakarta: Gadjah Mada University Press

Sugiyono, 2017.Metode Penelitian Kualitatif. Bandung : Alfabeta

Undang-Undang Republik Indonesia Nomor 41 Tahun 1999 Tentang Kehutanan, (Online), (https://jdih.kemenkeu.go.id/fulltext/1999/41TAHUN 1999UU.htm), diakses 20 September 2018

Yunus, Hadi Sabari. 2008. Konsep dan Pendekatan Geografi (Memaknai Hakikat Keilmuan). Yogyakarta: Fakultas Geografi UGM 